\title{
Chloroquine for COVID-19 Infection
}

\author{
Nicholas Moore ${ }^{1}$
}

Published online: 7 April 2020

(c) Springer Nature Switzerland AG 2020

The world is currently in the throes of the pandemic coronavirus infection, called COVID-19. Caused by a new virus, SARS-CoV2, COVID-19 is related to the common cold and the SARS-CoV1 virus that was responsible for the 2003 Severe Acute Respiratory Syndrome (SARS) infection in Asia, causing about 8000 cases and 774 deaths (https://www. who.int/csr/sars/country/Table2004_04_21/en/), mostly in young persons. Some drugs had shown in vitro or experimental activity against SARS-CoV1 at the time, including chloroquine or hydroxychloroquine [1-4]. The present epidemic has already infected over 750,000 people worldwide and caused more than 36,000 deaths as of 31 March 2020 (https://www.who.int/docs/default-source/coronaviruse/ situation-reports/20200331-sitrep-71-covid-19.pdf?sfvrs $\mathrm{n}=4360 \mathrm{e} 92 \mathrm{~b} \_6$ ).

A French virologist, Prof. Raoult, went public on social media to promote the use of chloroquine to treat or prevent COVID-19. This was widely picked up, with persons demanding immediate chloroquine for all. The resulting rush on chloroquine has led to a severe shortage of the drug, and patients taking regular chloroquine or hydroxychloroquine for lupus or other systemic diseases had to stop their treatment due to a lack of supply. At least one person has died from chloroquine sulfate, used to clean a fish tank (https:// nyti.ms/2UvjSgT).

The recommendation by Prof. Raoult was based on theory [5], on the effects of the drug on coronavirus replication in vitro [1, 4, 6-8], and on experimental data [2] showing SARS-CoV inhibition [3], concluding to a hypothetical effect of hydroxychloroquine on COVID-19 [9] without clinical proof other than a non-randomized open study of 20 patients, purported to show extraordinary results on virus washout (notwithstanding a slew of typical biases) [10]. At the same time, a pilot randomized controlled trial conducted

Nicholas Moore

nicholas.moore@u-bordeaux.fr

1 Bordeaux PharmacoEpi, INSERM CIC1401, Bordeaux, France in China in 30 non-severe patients [11] found no effect of hydroxychloroquine, compared with current care, with most patients virus-free after a few days.

At this point in time, there is no clear indication that chloroquine or hydroxychloroquine have a favorable effect on the outcomes of COVID-19. A large, randomized clinical trial, DISCOVERY (ClinicalTrials.gov identifier: NCT04315948), comparing remdesivir, lopinavir-ritonavir, interferon $\beta 1-\mathrm{A}$, and chloroquine with standard of care in over 3000 patients, is under way and the first results should be reported soon.

Chloroquine and hydroxychloroquine have been used for a very long time to treat malaria and autoimmune diseases such as lupus or rheumatoid arthritis. Their adverse effects are well known and can be severe, from psychiatric effects to arrhythmia and sudden death [12] (https://www.franc e24.com/en/20200331-french-watchdog-warns-of-dange rous-side-effects-of-unproven-covid-19-coronavirus-treat ments). Promoting their use indiscriminately and without any objective evidence is unconscionable, and certainly not medically responsible.

Of course, chloroquine and hydroxychloroquine might well end up being miracle drugs, but until this is proven, considering the generally favorable outcome of the SARSCoV2 infection, where most patients are asymptomatic or with mild symptoms, and the risks of these drugs, they cannot be recommended. Social distancing remains the only proven prevention of COVID-19 and its potentially very severe or fatal outcomes.

\section{Compliance with Ethical Standards}

Funding No sources of funding were used to assist in the preparation of this editorial.

Conflicts of interest Nicholas Moore has no conflicts of interest that are directly relevant to the content of this editorial. 


\section{References}

1. Keyaerts E, Vijgen L, Maes P, Neyts J, Van Ranst M. In vitro inhibition of severe acute respiratory syndrome coronavirus by chloroquine. Biochem Biophys Res Commun. 2004;323(1):264-8.

2. Keyaerts E, Li S, Vijgen L, Rysman E, Verbeeck J, Van Ranst M, et al. Antiviral activity of chloroquine against human coronavirus OC43 infection in newborn mice. Antimicrob Agents Chemother. 2009;53(8):3416-21.

3. De Clercq E. Potential antivirals and antiviral strategies against SARS coronavirus infections. Expert Rev Anti Infect Ther. 2006;4(2):291-302.

4. Vincent MJ, Bergeron E, Benjannet S, Erickson BR, Rollin PE, Ksiazek TG, et al. Chloroquine is a potent inhibitor of SARS coronavirus infection and spread. Virol J. 2005;2:69.

5. Devaux CA, Rolain JM, Colson P, Raoult D. New insights on the antiviral effects of chloroquine against coronavirus: what to expect for COVID-19? Int J Antimicrob Agents. 2020. https://doi. org/10.1016/j.ijantimicag.2020.105949.

6. Kono M, Tatsumi K, Imai AM, Saito K, Kuriyama T, Shirasawa H. Inhibition of human coronavirus $229 \mathrm{E}$ infection in human epithelial lung cells (L132) by chloroquine: involvement of p38 MAPK and ERK. Antivir Res. 2008;77(2):150-2.

7. Wang M, Cao R, Zhang L, Yang X, Liu J, Xu M, et al. Remdesivir and chloroquine effectively inhibit the recently emerged novel coronavirus (2019-nCoV) in vitro. Cell Res. 2020;30(3):269-71.
8. Yao X, Ye F, Zhang M, Cui C, Huang B, Niu P, et al. In vitro antiviral activity and projection of optimized dosing design of hydroxychloroquine for the treatment of severe acute respiratory syndrome coronavirus 2 (SARS-CoV-2). Clin Infect Dis. 2020. https://doi.org/10.1093/cid/ciaa237 (Epub 9 Mar 2020).

9. Multicenter Collaboration Group of Department of Service and Technology of Guangdong Province and Health Commission of Guangdong Province for chloroquine in the treatment of novel coronavirus pneumonia. Expert consensus on chloroquine phosphate for the treatment of novel coronavirus pneumonia [in Chinese]. Zhonghua Jie He He Hu Xi Za Zhi. 2020;43(3):185-8.

10. Gautret P, Lagier JC, Parola P, Hoang VT, Meddeb L, Mailhe $\mathrm{M}$, et al. Hydroxychloroquine and azithromycin as a treatment of COVID-19: results of an open-label non-randomized clinical trial. Internat J Antimicrob Agents. 2020. https://doi.org/10.1016/j.ijant imicag.2020.105949 (Epub 20 Mar 2020).

11. Chen J, Liu D, Liu L, Liu P, Xu Q, Xia L, et al. A pilot study of hydroxychloroquine in treatment of patients with common coronavirus disease-19 (COVID-19). J Zhejiang Univ (Med Sci). 2020. https://doi.org/10.3785/j.issn.1008-9292.2020.03.03.

12. Chatre C, Roubille F, Vernhet H, Jorgensen C, Pers YM. Cardiac complications attributed to chloroquine and hydroxychloroquine: a systematic review of the literature. Drug Saf. 2018;41(10):919-31. 